Original article

\title{
THE EFFECT OF DIFFERENT LEVELS OF PROPOLIS IN DIETS ON PERFORMANCE, GASTROINTESTINAL MORPHOLOGY AND SOME BLOOD PARAMETERS IN BROILER CHICKENS
}

\author{
A. SHADDEL-TILI, B. ESHRATKHAH, H. KOUZEHGARI \\ \& M. GHASEMI-SADABADI
}

Department of Animal Science, Faculty of Animal Science \& Veterinary

Medicine, Shabestar Branch, Islamic Azad University, Shabestar, Iran

\section{Summary}

Shaddel-Tili, A., B. Eshratkhan, H. Kouzehgari \& M. Ghasemi-Sadabadi, 2017. The effect of different levels of propolis in diets on performance, gastrointestinal morphology and some blood parameters in broiler chickens. Bulg. J. Vet. Med., 20, No 3, 215-224.

\begin{abstract}
A study was conducted to determine the effect of different levels of propolis in diets on performance, carcass characteristics, gastrointestinal morphology and some blood parameters in broiler chickens. A total of 224 one day-old Ross 308 chicks were randomly allocated to one of the 16 floor pens in a completely randomised design (four treatments, four replicate groups, 14 chicks in each group). Dietary treatments consisted of 4 different levels of propolis powder including zero (control), 500, 1500, $2000 \mathrm{ppm}$ in the diet throughout the entire experimental period (42 days). The feed was offered $\mathrm{ad}$ libitum. All the chickens were grown up in the same environmental and management conditions. Body weight gain, food intake and feed conversion ratio were measured at the end of each period, also, the production index was calculated at 42 days of age. At the end of experimental period, two chicks from each pen were selected and after blood sample collection were slaughtered and dissected manually. Haematological and biochemical parameters as well as carcass characteristics, gastrointestinal morphology were determined. The use of 2000 parts per million propolis powder in diet improved body weight gain, feed intake, feed conversion ratio and production index at all experimental periods $(\mathrm{P}<0.05)$. High dietary levels of propolis powder in diets increased the relative weight of crop, thighs and length of gizzard compared to other treatments, and decreased the relative weight of livers of broiler chickens $(\mathrm{P}<0.05)$. $\mathrm{PCV}$ and heterophil counts were significantly increased $(\mathrm{P}<0.05)$. It is suggested that the supplementation of propolis powder to poultry diets had a positive effect on growth performance, carcass characteristics and blood parameters.
\end{abstract}

Key words: broiler chickens, gastrointestinal morphology, haematology, propolis

\section{INTRODUCTION}

For many years, the propolis was considered like a waste, but recently, it obtained a great attention due to its multiple positive effects on human and animal health.
Nowadays, the propolis has become a high quality product in bee production. Several years ago, some unhealthy supplementation as antibiotics were used in 
poultry industry to improve performance in birds. In addition, antibiotics were prohibited due to its use in animal diet and adverse effects on human and animal health (Zulkifli et al., 2000; Apata, 2009).

The replacement of propolis in the diet may reduce the use of antibiotics and other unhealthy supplements in livestock and poultry diets. Moreover, in the many countries the use of antibiotic in animal diets has been prohibited (Casewell et al., 2003).

For this purpose, Orsi et al. (2000) reported that propolis influenced macrophage activation, it was shown that 5,10 and $20 \mathrm{~g} / \mathrm{mL}$ of propolis increased macrophage activation in $\mathrm{BALB} / \mathrm{c}$ mice. With regards to the humoral immune response, the propolis increases the antibody production in laboratory animals, macrophages activation by use of propolis in diets, which lead to cytokines production, regulating the functions of $\mathrm{B}$ and $\mathrm{T}$ cells, also higher antibody levels when propolis was administered in a short-term to the animals (Sforcin, 2007).

The propolis powder is a natural food supplement produced by honeybees (Apis mellifera). It is collected from substances of the different parts of plants, buds and exudates by bees (Fischer \& Vidor, 2008; Vatansever et al., 2010). The propolis is generally composed of $50 \%$ resin-vegetal balsam, 30\% beeswax, 10\% essential aromatic oils, $5 \%$ pollen and $5 \%$ other organic substances (Kumova et al., 2002; Dodologlu et al., 2003). However, the propolis compositions are various (Tortei et al., 2013), its colour is dark brown, but can be found in green, red, black, and white hues.

The use of propolis powder in animal nutrition and increased quality of diets can be related to some vitamins, minerals and enzymes in its composition and important high content of flavonoids, phenolic acid and terpenoids (Kumova et al., 2002; Yilmaz et al., 2003). Propolis has been extensively used in traditional medicine due to its several pharmacological and biological properties - antimicrobial, immunomodulatory, anti-inflammatory and antioxidant (Nakamura et al., 2010; Vatansever et al., 2010). The pharmacological activity of propolis against several viral infections has been evaluated in vitro with some viruses (Nolkemper et al., 2010) and it was found out that one of the important biological activities of the propolis was its antimicrobial activity. According to this fact, the use of propolis in BALB/c mice diets is significantly effective in different bacteria, viruses and fungi (Murad et al., 2002).

Tayeb \& Sulaiman (2014) carried out a study to assess the effect of propolis supplementation in water on performance and some physiological and immunological characteristics in local quails at 42 days of age and observed that the supplementation of quail water with propolis significantly increased live body weight, carcass weight compared to control group. Therefore, the use of propolis in broiler chickens diet can have a beneficial effect on blood parameters. Petruska et al. (2012) reported that the addition of propolis to broiler chickens diet caused significant $(\mathrm{P}<0.05)$ decrease in serum phosphorus and magnesium in all experimental groups in comparison with the control group. The increase in the food costs and the resultant shortage in animal protein supply have encouraged the exploitation of local, available and cheap animal and health meats to forestall threat to the future of poultry production (Agiang et al., 2011).

Nowadays, the use of herbal and natural source as propolis are very important 
factors for improvement of the performance and immune system in broiler chickens. On the other hand, the propolis supplementation can reduce the antibiotic application in broiler chickens diet, which is directly related to the human health. Therefore, this study aimed to evaluate the effect of different levels of propolis in diets on performance traits, carcass characteristics, gastrointestinal morphology, some blood biochemical and haematological parameters in broiler chickens.

\section{MATERIALS AND METHODS}

\section{Experimental design}

A total of 224 one day old, male and female Ross 308 broiler chickens, were randomly allocated to 16 floor pens in a completely randomised design with four treatments, four replicates and 14 chicks in each replicate.

The broiler chickens were housed in floor pens $1 \times 1.5 \mathrm{~m}^{2}$ and kept under similar management conditions according to the Ross 308 strain catalogue. Animal handling and experimental procedures were performed according to the Guide for the Care and Use of Laboratory Animals by the National Institute of Health (USA) and the current laws for animal care of the Iranian government. The feed and water were available ad libitum. The basal diets were corn and soybean meal and then different percentages of propolis were added to the basal diets at zero (control), 500, 1500, and 2000 parts per million. The diets (Table 1) were formulated according to National Research Council (NRC, 1994).

\section{Collection and processing of propolis}

The propolis was collected from the West Azerbaijan province in the different hill- side near the Turkish and Iraqi border. The propolis samples were kept desiccated in dark until the processing. The propolis was collected in a plastic alimentary tarpaulin, and then packaged rapidly in plastic bags. The storage has to be done in a cool, dry and dark room but a cold room would be ideal in order to avoid the growth of tinea and to preserve all active ingredients of the propolis. The collected propolis was extracted for a week with $100 \mathrm{~mL} 70 \%$ ethanol at room temperature to obtain the extract. After filtration, the extract was evaporated using a vacuum evaporator at $50{ }^{\circ} \mathrm{C}$ and then, was used in the experiment.

\section{Performance and carcass characteristics}

At the end of each period, feed consumption, body weight gain and feed conversion ratio were measured. At end of the trial, production index for the whole period of breeding was calculated.

At 42 days of age, two chicks from each group were selected slaughtered and dissected manually. The relative weights of different body organs that included eviscerated carcass, liver, breast, thigh, abdominal fat, proventriculus, esophagus, crop, caecum, small intestine and colon were recorded and expressed as a percentage of body weight. The size of the proventriculus, esophagus, crop, caecum, small intestine and colon was expressed in centimeters.

\section{Analysis of blood parameters}

Two chicks from each group were sacrificed on days 42 by collecting blood samples from the brachial vein in anticoagulated tubes (EDTA $1 \mathrm{mg} / \mathrm{mL}$ blood). Erythrocyte and leukocyte counts were determined on a haemocytometer according 
The effect of different levels of propolis in diets on performance, gastrointestinal morphology and ....

Table 1. Composition and calculated nutrient content of broilers' diet during the experimental period

\begin{tabular}{lccc}
\hline & & Diets & \\
\cline { 2 - 4 } Ingredients (\%) & Starter & Grower & Finisher \\
\hline Corn & 55.00 & 58.00 & 61.25 \\
Soybean meal (44\% CP) & 36.55 & 31.15 & 29.50 \\
Corn meal & 1.50 & 4.00 & 1.00 \\
Sunflower oil & 3.20 & 3.20 & 5.00 \\
Dicalcium phosphate & 1.80 & 1.60 & 1.50 \\
Shell powder & 1.40 & 1.20 & 1.20 \\
Common salt & 0.02 & 0.02 & 0.02 \\
Vitamin premix a & 0.25 & 0.25 & 0.25 \\
Mineral premix b & 0.25 & 0.25 & 0.25 \\
DL-methionine & 0.02 & 0.02 & 0.02 \\
L-lysine mono hydrochloride & 0.01 & 0.01 & 0.01 \\
\hline Calculated analysis & & & \\
\hline ME (kcal/kg) & 3017.8 & 3145.4 & 3207.9 \\
Crude protein (\%) & 21.84 & 21.23 & 18.99 \\
Calcium (\%) & 1.02 & 0.90 & 0.87 \\
Available phosphorus (\%) & 0.49 & 0.46 & 0.42 \\
Methionine (\%) & 0.36 & 0.39 & 0.31 \\
Lysine (\%) & 1.15 & 0.99 & 0.95 \\
Tryptophan (\%) & 0.60 & 0.59 & 0.58 \\
Methionine + cysteine (\%) & 0.70 & 0.71 & 0.62 \\
\hline
\end{tabular}

${ }^{\text {a }}$ Vitamin and mineral premix supplying per kg diet: vitamin A (from vitamin A acetate), $10000 \mathrm{IU}$; vitamin $_{\mathrm{D} 3}, 9790 \mathrm{IU}$; vitamin $\mathrm{E}$ (dl-tocopheryl acetate), $30 \mathrm{IU}$; vitamin $\mathrm{B}_{12}, 20 \mu \mathrm{g}$; riboflavin, $4.4 \mathrm{mg}$; calcium pantothenate, $40 \mathrm{mg}$; niacin, $22 \mathrm{mg}$; choline, $840 \mathrm{mg}$; biotin, $30 \mu \mathrm{g}$; thiamine, $4 \mathrm{mg}$; zinc sulfate, $60 \mathrm{mg}$; copper sulfate, $100 \mu \mathrm{g}$; selenium (sodium selenate), $0.2 \mathrm{mg}$; iodine, $1 \mathrm{mg}$; manganese oxide, $60 \mathrm{mg}$. ${ }^{\text {b }}$ Providing per kg diet: $\mathrm{Mn}, 99.2 \mathrm{mg}$; Fe, $50 \mathrm{mg}$; Zn, $84.7 \mathrm{mg}$; Cu, $10 \mathrm{mg}$; I, 0.99 mg; $\mathrm{Se}, 0.2 \mathrm{mg}$; choline chloride, $250 \mathrm{mg}$.

to Natt \& Herrick (1952). Packed cell volume (PCV) was determined using haematocrit tubes. The cyanmethaemoglobin method as described by Benjamin (1978) was used to estimate haemoglobin content $\mathrm{Hb}$. The samples were centrifuged at $3000 \mathrm{rpm}$ for $13 \mathrm{~min}$, and stored at $-20{ }^{\circ} \mathrm{C}$ until analysed for total protein and triglycerides on a Technicon RA-1000 Autoanalyzer (Technicon Instruments Corp., USA).

\section{Statistical analysis}

Data were subjected to one-way analysis of variance by applying the SAS program
(SAS, 2005) using a general liner model (GLM). Significant differences among treatment means were evaluated using Tukey's test (Abdi, 2009) at 5\% probability.

\section{RESULTS}

\section{Performance}

The effect of different levels of propolis in diets on body weight gain, feed consumption, feed conversion ratio and production index in broiler chickens were shown on Table 2. The use of different levels of propolis powder in diets had 
Table 2. Effects of different levels of propolis in diets on performance in broiler chickens $(1-42$ days of age). Data are presented as mean \pm standard deviation $(n=8)$

\begin{tabular}{|c|c|c|c|c|}
\hline & \multicolumn{4}{|c|}{ Treatments } \\
\hline & Control & $500 \mathrm{ppm}$ & $1500 \mathrm{ppm}$ & $2000 \mathrm{ppm}$ \\
\hline \multicolumn{5}{|c|}{ Body weight gain (g) } \\
\hline $\begin{array}{l}\text { Day } 1-10 \\
\text { Day } 11-24 \\
\text { Day } 25-42 \\
\text { Day } 1-42 \\
\end{array}$ & $\begin{array}{l}167.90 \pm 7.12^{\mathrm{b}} \\
594.07 \pm 9.26^{\mathrm{c}} \\
1218.07 \pm 41.26^{\mathrm{c}} \\
1980.03 \pm 54.61^{\mathrm{c}} \\
\end{array}$ & $\begin{array}{l}175.00 \pm 4.21^{\mathrm{bc}} \\
620.57 \pm 6.98^{\mathrm{c}} \\
1319.27 \pm 29.26^{\mathrm{c}} \\
2115.97 \pm 39.61^{\mathrm{c}}\end{array}$ & $\begin{array}{l}191.20 \pm 3.12^{\mathrm{ab}} \\
661.03 \pm 6.12^{\mathrm{b}} \\
1452.20 \pm 26.26^{\mathrm{b}} \\
2304.43 \pm 35.61^{\mathrm{b}} \\
\end{array}$ & $\begin{array}{l}211.56 \pm 6.36^{\mathrm{a}} \\
749.63 \pm 8.12^{\mathrm{a}} \\
1616.34 \pm 39.78^{\mathrm{a}} \\
2557.53 \pm 49.61^{\mathrm{a}}\end{array}$ \\
\hline \multicolumn{5}{|c|}{ Feed consumption (g) } \\
\hline $\begin{array}{l}\text { Day } 1-10 \\
\text { Day } 11-24 \\
\text { Day } 25-42 \\
\text { Day } 1-42\end{array}$ & $\begin{array}{l}243.33 \pm 8.21^{\mathrm{b}} \\
885.33 \pm 27.11^{\mathrm{c}} \\
2674.67 \pm 28.01^{\mathrm{c}} \\
3803.34 \pm 33.41^{\mathrm{c}}\end{array}$ & $\begin{array}{l}240.66 \pm 7.90^{b} \\
885.00 \pm 26.09^{c} \\
2676.67 \pm 28.09^{c} \\
3804.67 \pm 30.12^{c}\end{array}$ & $\begin{array}{l}258 \pm 7.20^{\mathrm{ab}} \\
916.66 \pm 23.61^{\mathrm{b}} \\
2783.67 \pm 26.09^{\mathrm{b}} \\
3958.33 \pm 30.12^{\mathrm{b}}\end{array}$ & $\begin{array}{l}271.33 \pm 9.53^{\mathrm{a}} \\
951.66 \pm 32.74^{\mathrm{a}} \\
2930.00 \pm 33.72^{\mathrm{a}} \\
4133.00 \pm 37.14^{\mathrm{a}}\end{array}$ \\
\hline
\end{tabular}

Feed conversion ratio

\begin{tabular}{|c|c|c|c|c|}
\hline Day $1-10$ & $1.45^{\mathrm{a}}$ & $1.39^{\mathrm{ab}}$ & $1.35^{\mathrm{bc}}$ & $1.28^{\mathrm{c}}$ \\
\hline Day 11-24 & $1.47^{\mathrm{a}}$ & $1.41^{\mathrm{ab}}$ & $1.38^{\mathrm{b}}$ & $1.27^{\mathrm{c}}$ \\
\hline Day 25-42 & $2.20^{\mathrm{a}}$ & $2.03^{c}$ & $1.91^{\mathrm{cb}}$ & $1.81^{\mathrm{c}}$ \\
\hline Day $1-42$ & $1.91^{\mathrm{a}}$ & $1.79^{\mathrm{b}}$ & $1.71^{\mathrm{c}}$ & $1.60^{\mathrm{d}}$ \\
\hline
\end{tabular}

Production index

\begin{tabular}{lllll} 
Day $1-42$ & $226.10 \pm 8.97^{\mathrm{c}}$ & $241.53 \pm 6.68^{\mathrm{c}}$ & $266.73 \pm 6.31^{\mathrm{b}}$ & $288.70 \pm 10.25^{\mathrm{a}}$ \\
\hline
\end{tabular}

${ }^{a, b, c}$ means in columns with different superscripts differ significantly $(\mathrm{P}<0.05)$.

significant effects on body weight gain, feed consumption and feed conversion ratio $(\mathrm{P}<0.05)$ The addition of $2000 \mathrm{ppm}$ propolis powder to the diet significantly increased body weight gain, feed consumption and decreased feed conversion ratio compared to other groups $(\mathrm{P}<0.05)$. At the end of trial, the production index was significantly $(\mathrm{P}<0.05)$ higher in the $2000 \mathrm{ppm}$ group than in other groups $(P<0.05)$. Generally, the results showed that the use of $2000 \mathrm{ppm}$ propolis powder in the diet increased body weight gain, feed consumption and improved feed conversion ratio $(\mathrm{P}<0.05)$.

\section{Carcass and gastrointestinal organ characteristics}

The effect of different levels of propolis in diets on gastrointestinal organ and car- cass characteristics in broiler chickens are shown on Tables $3 \& 4$. The liver weight was significantly higher in control group compared to other groups $(\mathrm{P}<0.05)$. In addition, the crop and thigh weights were significantly higher in the $2000 \mathrm{ppm}$ and $1500 \mathrm{ppm}$ groups respectively, compared to other groups. Gizzard was longer in chickens supplemented with $1500 \mathrm{ppm}$ propolis powder $(6.32 \mathrm{~cm})$ than in other groups $(\mathrm{P}<0.05)$. However, there were no significant differences between the experimental groups and control groups regarding the supplementation with propolis powder on other carcass and gastrointestinal organ characteristics.

\section{Blood parameters}

The effect of different levels of propolis in rations on blood parameters in broiler 
The effect of different levels of propolis in diets on performance, gastrointestinal morphology and ....

Table 3. Effects of different levels of propolis in diets on gastrointestinal organ in broiler chickens at 42 days of age. Data are presented as mean \pm standard deviation $(n=8)$

\begin{tabular}{|c|c|c|c|c|}
\hline & \multicolumn{4}{|c|}{ Propolis treatments } \\
\hline & Control & $500 \mathrm{ppm}$ & $1500 \mathrm{ppm}$ & $2000 \mathrm{ppm}$ \\
\hline \multicolumn{5}{|c|}{ Gastrointestinal organ (\% of body weight) } \\
\hline $\begin{array}{l}\text { Proventriculus (\%) } \\
\text { Esophagus (\%) } \\
\text { Gizzard (\%) } \\
\text { Crop (\%) } \\
\text { Small intestine (\%) } \\
\text { Caecum (\%) } \\
\text { Colon }(\%) \\
\end{array}$ & $\begin{array}{l}0.075 \pm 0.35 \\
0.33 \pm 0.0008 \\
1.45 \pm 0.12 \\
0.197 \pm 0.007^{\mathrm{b}} \\
1.92 \pm 0.11 \\
0.21 \pm 0.01 \\
0.105 \pm 0.08 \\
\end{array}$ & $\begin{array}{l}0.077 \pm 0.30 \\
0.33 \pm 0.0007 \\
1.43 \pm 0.10 \\
0.197 \pm 0.008^{b} \\
1.90 \pm 0.13 \\
0.23 \pm 0.03 \\
0.115 \pm 0.06 \\
\end{array}$ & $\begin{array}{l}0.077 \pm 0.32 \\
0.33 \pm 0.0007 \\
1.35 \pm 0.20 \\
0.192 \pm 0.010^{b} \\
2.02 \pm 0.20 \\
0.22 \pm 0.02 \\
0.130 \pm 0.03 \\
\end{array}$ & $\begin{array}{l}0.082 \pm 0.41 \\
0.32 \pm 0.0009 \\
1.50 \pm 0.17 \\
0.227 \pm 0.012^{\mathrm{a}} \\
1.95 \pm 0.08 \\
0.21 \pm 0.01 \\
0.137 \pm 0.03 \\
\end{array}$ \\
\hline \multicolumn{5}{|c|}{ Gastrointestinal organs length } \\
\hline $\begin{array}{l}\text { Proventriculus }(\mathrm{cm}) \\
\text { Esophagus }(\mathrm{cm}) \\
\text { Gizzard }(\mathrm{cm}) \\
\text { Crop }(\mathrm{cm}) \\
\text { Small intestine }(\mathrm{cm}) \\
\text { Caecum }(\mathrm{cm}) \\
\text { Colon }(\mathrm{cm})\end{array}$ & $\begin{array}{c}7.07 \pm 0.66 \\
4.12 \pm 0.18 \\
5.27 \pm 0.34^{\mathrm{b}} \\
5.55 \pm 0.38 \\
175.87 \pm 7.8 \\
18.52 \pm 0.61 \\
9.72 \pm 0.84 \\
\end{array}$ & $\begin{array}{r}7.20 \pm 0.63 \\
4.47 \pm 0.19 \\
5.21 \pm 0.38^{\mathrm{b}} \\
5.87 \pm 0.32 \\
177.05 \pm 6.96 \\
18.52 \pm 0.68 \\
9.56 \pm 0.77 \\
\end{array}$ & $\begin{array}{c}7.55 \pm 0.53 \\
4.31 \pm 0.12 \\
6.32 \pm 0.43^{\mathrm{a}} \\
5.51 \pm 0.39 \\
182.85 \pm 6.7 \\
19.13 \pm 0.67 \\
9.20 \pm 0.82\end{array}$ & $\begin{array}{c}7.87 \pm 0.67 \\
4.47 \pm 0.16 \\
5.98 \pm 0.30^{\mathrm{ab}} \\
6.01 \pm 0.38 \\
182.85 \pm 6.6 \\
19.13 \pm 0.68 \\
9.20 \pm 0.80\end{array}$ \\
\hline
\end{tabular}

Table 4. Effects of different levels of propolis in diets on carcass characteristics and blood parameters in broiler chickens at 42 days of age. Data are presented as mean \pm standard deviation $(n=8)$

\begin{tabular}{lcccc}
\hline & \multicolumn{4}{c}{ Propolis treatments } \\
\cline { 2 - 5 } & Control & $500 \mathrm{ppm}$ & $1500 \mathrm{ppm}$ & $2000 \mathrm{ppm}$ \\
\hline Carcass characteristics & & & \\
Carcass yield (\%) & $76.27 \pm 0.80$ & $75.75 \pm 0.91$ & $76.42 \pm 0.84$ & $76.12 \pm 0.79$ \\
Liver (\%) & $2.45 \pm 0.24^{\mathrm{a}}$ & $2.37 \pm 0.15^{\mathrm{ab}}$ & $1.90 \pm 0.13^{\mathrm{c}}$ & $2.02 \pm 0.11^{\mathrm{bc}}$ \\
Breast (\%) & $33.15 \pm 0.13$ & $35.67 \pm 0.91$ & $34.72 \pm 0.95$ & $34.85 \pm 0.11$ \\
Thigh (\%) & $23.15 \pm 1.96^{\mathrm{c}}$ & $27.30 \pm 1.19^{\mathrm{ab}}$ & $29.62 \pm 1.24^{\mathrm{a}}$ & $28.62 \pm 1.20^{\mathrm{bc}}$ \\
Abdominal fat (\%) & $1.25 \pm 0.16$ & $1.40 \pm 0.10$ & $1.35 \pm 0.13$ & $1.45 \pm 0.11$ \\
\hline Haematological and biochemical parameters & & \\
WBC (x10 $/ \mu \mathrm{L})$ & $19.34 \pm 0.21$ & $19.88 \pm 0.29$ & $19.62 \pm 0.26$ & $19.35 \pm 0.23$ \\
RBC (x10\%/ $/ \mathrm{L}$ ) & $2.88 \pm 0.09$ & $2.79 \pm 0.06$ & $2.79 \pm 0.07$ & $2.79 \pm 0.06$ \\
Haemoglobin (g/L) & $77.30 \pm 2.24$ & $81.50 \pm 2.49$ & $76.50 \pm 2.34$ & $77.50 \pm 2.26$ \\
PCV (L/L) & $0.41 \pm 0.015$ & $0.41 \pm 0.013$ & $0.38 \pm 0.018$ & $0.41 \pm 0.015$ \\
Heterophils (\%) & $22 \pm 1.9^{\mathrm{b}}$ & $25 \pm 1.2^{\mathrm{ab}}$ & $28 \pm 2.01^{\mathrm{a}}$ & $25 \pm 1.2^{\mathrm{ab}}$ \\
Lymphocytes (\%) & $66.25 \pm 3.01$ & $59.75 \pm 2.3$ & $59.00 \pm 2.6$ & $60.50 \pm 2.4$ \\
Eosinophils (\%) & $7.50 \pm 1.10$ & $8.00 \pm 1.42$ & $7.25 \pm 0.9$ & $7.25 \pm 1.00$ \\
Monocytes (\%) & $4.00 \pm 1.39$ & $6.25 \pm 1.11$ & $5.50 \pm 1.15$ & $7.00 \pm 1.27$ \\
Triglyceride & $0.44 \pm 0.09$ & $0.33 \pm 0.08$ & $0.36 \pm 0.05$ & $0.42 \pm 0.05$ \\
(mmol/L) & & & & \\
Total protein (g/L) & $29.90 \pm 1.85$ & $34 \pm 1.76$ & $33 \pm 1.74$ & $32.1 \pm 1.65$ \\
\hline
\end{tabular}

${ }^{a, b, c}$ means in columns with different superscripts differ significantly $(\mathrm{P}<0.05)$. 
chickens were shown on Table 4. The heterophils percentage was significantly higher in birds fed propolis powder in the diet compared to control group $(\mathrm{P}<0.05)$. The heterophils percentage in birds fed 1500 ppm was significantly higher than in birds which received the other treatments. On other hand, chicks fed diet supplemented with propolis powder showed no significant differences in lymphocyte, monocyte and eosinophil counts.

\section{DISCUSSION}

Regarding the data, it can be concluded that the use of propolis powder in broiler chickens diet improved the body weight gain, feed consumption and feed conversion ratio in broiler chickens. Also, it seems that the use of $2000 \mathrm{ppm}$ propolis powder levels in broiler chickens diets had significantly higher effect on performance traits. The results of this research were in agreement with findings of other authors (Acikgoz et al., 2005; Seven et al., 2008; 2011) showing that the use of high level of propolis powder in broiler diets linearly improved the performance in broiler chickens. In addition, Shalmany \& Shivazad (2006) reported that use of propolis in broiler chickens diet increased body weight gain and feed consumption during the entire rearing period. Tayeb \& Sulaiman (2014) showed that supplementation of $400 \mathrm{mg} / \mathrm{L}$ propolis in diets improved feed consumption and feed conversion ratio of broiler chickens. Our results were in agreement with the findings of Shalmany \& Shivazad (2006) and Seven et al. (2008; 2011) who reported that the supplement of high levels of propolis powder in diets increased feed conversion ratio and feed consumption in broiler chicken.
Generally, it seems that, in this study chickens with high dietary propolis levels showed better performance than those with low level propolis in diets. This can be due to the composition of propolis which is known to include protein, amino acids, vitamins ( $\mathrm{A}, \mathrm{B}_{1}, \mathrm{~B}_{2}, \mathrm{~B}_{3}$ and biotin), flavonoids and minerals, which are important in increasing the growth performance (Aziz, 1981). Also, these findings can be due to the antimicrobial potential of the components of the propolis, resulting in better intestinal health and improving digestion and absorption (Tayeb \& Sulaiman, 2014). Shalmany \& Shivazad (2006); Seven et al. (2008; 2011) showed that the dietary supplementation of propolis had significant effect on mortality rate by improving the immunity and performance. In this study, the liver and crop weights differed between various propolis levels in diets. Similarly, Seven et al. (2011) showed higher crop and liver weight by using propolis powder in diets. The higher weights of carcass and gastrointestinal organ characteristics in our study were due to the antimicrobial and antioxidants activity of propolis resulting in better intestinal health and improved digestion and absorption (Orhan et al., 1999). In addition, the high weight of crop and thigh, as well as gizzard length can be related to the high food consumption in treated groups.

In the present study, the use of propolis powder in diets had no significant effect on carcass yield, in agreement with the finding of Seven et al. (2011).

The results of this work showed that the use of propolis in diet had not influenced erythrocyte and leukocytes counts, PCV and haemoglobin concentration of broiler chickens $(\mathrm{P}>0.05)$. Moreover, the heterophils were increased in birds supplemented with high propolis levels. Ab- 
del-Rahman \& Mosaad (2013) reported that the use of propolis in diet did not affect leukocytes counts and haemoglobin concentration in broiler chickens. Our results agree with the study of Galal et al. (2008) who reported that the use of 100 and $150 \mathrm{mg}$ propolis in broiler chickens diet indicated high packed cell volume in laying hens. Hence, Omar et al. (2003) showed that the use of propolis in diet improved the haemoglobin, packed cell volume, erythrocyte counts.

The use of $1500 \mathrm{ppm}$ propolis powder in broiler chickens diets resulted in significantly higher heterophil counts compared to other treatments in this experiment $(\mathrm{P}<0.05)$. Our results agree with finding of Omar et al. (2003) who indicated that the supplementation of propolis in diets increased heterophils counts in broiler chickens. Bratter et al. (1999) reported that the alcoholic extract of propolis had immunostimulating effect and maintained good health. In addition, the high heterophils percentage can be related to the ability of propolis to activate the macrophages (Sforcin, 2007).

Grange \& Davey (1990) affirmed that propolis contained flavonoids with antibacterial activity. Costantini \& Dell'omo (2006) observed positive effects of flavonoids on immune responsiveness might have a variety of underlying mechanisms because flavonoids activated immune cells. The results of the current study revealed that the use of propolis powder in diet did not affect the blood triglyceride and total protein level in broiler chickens. Denli et al. (2005) indicated that the use of different levels of propolis powder in diet had no effect on serum total proteins, albumin, globulins and glucose in Japanese quail fed different levels of propolis powder. In contrast with this finding, Althnaian (2014) established that blood cholesterol and triglycerides level in rats were increased by supplementing diets with propolis powder.

It can be concluded from this study that the use of propolis powder in diet had positive effects on growth performance, Also, the dietary supplementation of propolis at a level higher than $1500 \mathrm{ppm}$ had better effects on performance traits, carcass characteristics and blood parameters in broiler chickens.

\section{ACKNOWLEDGMENTS}

This article is a part of M.Sc. thesis in Animal Science, Islamic Azad University of Shabestar Branch (thesis supervisor: Dr. A. ShaddelTili). Thanks are expressed to Mohammad Ghasemi-Sadabadi for his assistance in this study. Thanks also to Dr. Farid Tofigh Nia (Neurologist) and Mr. Mojtaba Didevar for his kind support of this study.

\section{REFERENCES}

Abdel-Rahman, M. A. \& G. M. Mosaad, 2013. Effect of propolis as additive on some behavioral patterns, performance and blood parameters in Muscovy broiler ducks. Journal of Advanced Veterinary Research, 3, 64-68.

Abdi, H. B., Edelman, D. Valentin \& W. J. Dowling, 2009. Experimental Design and Analysis for Psychology. Oxford: Oxford University Press.

Acikgoz, Z., B. Yucel \& O. Aitan, 2005. The effects of propolis supplementation on broiler performance and feed digestibility. Archiv für Geflugelkunde, 69, 117-122.

Aghdam-Shahryar, H., M. Namvari, H. Nourollahi \& A. Shaddel-Tili, 2011. Effect of alcoholic extract propolis on immune system in broiler chickens. Journal of Basic and Applied Scientific Research, 1, 2094-2097.

Agiang, E. A., O. O. K. Oko \& G. E. Essien, 2011. Quails response to aqueous extract 
of bush marigold (Aspilia africana) leaf. American Journal of Animal and Veterinary Sciences, 6, 130-134.

Althnaian, T., 2014. Influence of dietary supplementation of Garden cress (Lepidium sativum $L$.) on liver histopathology and serum biochemistry in rats fed high cholesterol diet. Journal of Advanced Veterinary and Animal Research, 1, 216-223.

Apata, D. F., 2009. Antibiotic resistance in poultry. International Journal of Poultry Science, 8, 404-408.

Aziz, M. A., 1981. Growth promoting agents. In: Handbook of Veterinary Pharmacol$o g y$, ed M. A. Aziz, Zagazig University, pp. 290-295.

Benjamin, M. M., 1978. Outline of Veterinary Clinical Pathology, $3^{\text {rd }}$ edn, The Iowa State University Press. Ames, IA.

Bratter., C., M. Tregel, C. Liebenthal \& H. Volk, 1999. Prophylactic effectiveness of propolis for immunostimulation: a clinical pilot study. Forschende Komplementärmedizin und Klassische Naturheilkunde, $\mathbf{6}$, 256-260.

Casewell, M., C. Friis, E. Marco, P. Mcmullin \& I. Phollips. 2003. The European ban on growth-promoting antibiotics and emerging consequences for human and animal health. Journal of Antimicrobial Chemotherapy, 52,159-161.

Costantini, D. \& G. Dell'omo, 2006. Effects of T-cell-mediated immune response on avian oxidative stress. Comparative Biochemistry and Physiology A - Molecular and Integrative Physiology, 145, 137-142.

Denli, M., S. Cankaya, S. Silici, F. Okan \& A. N. Uloucak, 2005. Effect of dietary addition of turkish propolis on the growth performance, carcass characteristics and serum variables of quail (Coturnix coturnix japonica). Asian-Australasian Journal of Animal Sciences, 26, 848-854.

Dodologlu, A., S. Kultuca \& F. Genc, 2003. Application area and production of propolis. In: Proceedings of the $2^{\text {nd }}$ Marmara Apiculture Congress, April 28-30, Yalova.
Fischer, G. \& T. Vidor, 2008. Propolis as an immune system modulator substance. In: Scientific Evidence of the Use of Propolis in Ethnomedicine, eds N. Orsolic \& I. Basic (eds), Trans world Research Network, Kerala.

Galal, A., A. M. Abdel-Motaal, A. M. H. Ahmed \& T. G. Zaki, 2008. Productive performance and immune response of laying hens as affected by dietary propolis supplementation. International Journal of Poultry Science, 7, 272-278.

Grange, J. M., \& R. W. Davey, 1990. Antibacterial properties of propolis (bee glue). Journal of the Royal Society of Medicine, 83, 159-160.

Kumova, U., A. Korkmaz, B. C. Avci \& G. Ceyran, 2002. An important bee product: propolis. Uludag Bee Journal, 2, 10-24.

Murad, J. M., S. A. Calvi, A. M. V. C. Soares, V. Bankova \& J. M. Sforcin, 2002. Effects of propolis from Brazil and Bulgaria on fungicidal activity of macrophages against paracoccidioides brasiliensis. Journal of Ethnopharmacology, 79, 331-334.

Nakamura, R., R. Nakamura, K. Watanabe, K. Oka, S. Ohta, S. Mishima \& R. Teshima, 2010. Effects of propolis from different areas on mast cell degranulation and identification of the effective components in propolis. International Immunopharmacology, 10, 1107-1112.

National Research Council, 1994. Nutrient requirements of poultry. $9^{\text {th }}$ edn, National Academy Press, Washington, D.C., U.S.A.

Natt, M. P. \& C. A. Herrick, 1952. A new diluent for counting the erythrocytes and leukocytes for the chicken. Poultry Science, 31, 735-737.

Nolkemper, S., J. Reichling, K. H. Sensch \& P. Schnitzler, 2010. Mechanism of herpes simplex virus type 2 suppression by propolis extracts. Phytomedicine, 17, 132-138.

Omar, R. E. M., E. A. Mahmoud., M. M. Karusa \& A. A. Randa. 2003. Effect of additives propolis and Nigella sativa seed oil on some behavioral patterns, performance products and blood parameters in Sasso 
The effect of different levels of propolis in diets on performance, gastrointestinal morphology and ....

chickens. Egyptian Poultry Science, 21, 140-151.

Orsi, R. O., S. R. C. Funari, A. M. V. C. Soares, S. A. Calvi, S. L. Oliveira, J. M. Sforcin \& V. Bankova. 2000. Immunomodulatory action of propolis on macrophage activation. Journal of Venomous Animals and Toxins Including Tropical Diseases. 6, 205-219.

Orhan, H., S. Marol, I. F. Hepsen \& G. Sahin, 1999. Effects of some probable antioxidants on selenite induced cataract formation and oxidative stress-related parameters in rats. Toxicology, 139, 219-232.

Petruska, P., E. Tusimova, A. Kalafova, P. Hascik, A. Kolesarova, M. Capcarova, 2012. Effect of propolis in chicken diet on selected parameters of mineral profile. Journal of Microbiology, Biotechnology and Food Sciences, 1, 593-600.

SAS Institute, 2005. SAS Users guide: Statistics, Version 9.12. SAS Institute Inc., Cary, NC, USA,

Serkedjieva, J., N. Manolova \& V. Bankove, 1992. Anti-influenza virus effect of some propolis constituents and their analogues (esters of substituted cinnamic acids). Journal of Natural Products, 55, 294-297.

Seven, P. T., I. Seven, M. Yilmaz \& U. G. Simsek, 2008. The effects of Turkish propolis on growth and carcass characteristics in broilers under heat stress. Animal Feed Science and Technology, 146, 137-148.

Seven, I., P. T. Seven \& S. Silci, 2011. Effects of dietary Turkish propolis as alternative to antibiotic on growth and laying performance, nutrient digestibility and egg quality in laying hens under heat stress. $R e$ vue de Médecine Vétérinaire, 162, 186-191.

Sforcin, J. M., 2007. Propolis and the immune system: a review. Journal of Ethnopharmacology, 113, 1-14.

Shalmany, S. K. \& M. Shivazad, 2006. The effect of diet propolis supplementation on ross broiler chicks performance. International Journal of Poultry Science, 5, 84-88.
Tayeb, I. T. \& B. F. Sulaiman, 2014. Effect of propolis supplementation on productive performance in local quail. Iranian Journal of Applied Animal Science, 4, 621-627.

Tortei, V. C., H. H. Sato, G. M. Pastore \& Y. K. Park, 2013. Recent progress of propolis for its biological and chemical compositions and its botanical origin. Evidence Based Complementary and Alternative Medicine. http://dx.doi.org/10.1155/2013/ 697390.

Vatansever, H. S., S. K. Sorkun, I. D. Gurhanb, F. O. Kurt, E. Turkoz, O. Gencay \& B. Salih, 2010. Propolis from Turkey induces apoptosis through activating caspases in human breast carcinoma cell lines. Acta Histochemica, 112, 546-556.

Yilmaz, L., T. O. Yilsay \& A. A. Bayazit, 2003. Chemical composition of propolis, properties and biological effects on human health. In: Proceedings of the $2^{\text {nd }}$ Marmara Apiculture Congress, April 28-30, Yalova.

Zulkifli, I., N. Abdullah \& N. Mohad, 2000. Growth performance and immune response of two commercial broiler strains fed diet containing lactobacillus cultures and oxytetracycline under heat poultry stress condition. British Poultry Science, 41, 593-597.

Paper received 21.12.2015; accepted for publication 26.02.2016

\section{Correspondence:}

Dr. Abdolahad Shaddel-Tili

Ph.D. of Animal Physiology

Department of Animal Science,

Faculty of Animal Science and Veterinary

Medicine, Shabestar Branch,

Islamic Azad University,

5381637181Shabestar, Iran

Tel: +98-471-2225311

Fax: +98-471-2224927

E-mail: Shaddel_a@yahoo.com 